\title{
Atmospheric Fronts along the East Coast of Taiwan Studied by ERS Synthetic Aperture Radar Images
}

\author{
WERnER AlPERS \\ Zentrum für Meeres- und Klimaforschung, Institut für Meereskunde, Universität Hamburg, Hamburg, Germany \\ Jen-Ping Chen, I.-I. Lin, And Chun-Chi Lien \\ Department of Atmospheric Sciences, National Taiwan University, Taipei, Taiwan
}

(Manuscript received 13 December 2005, in final form 19 June 2006)

\begin{abstract}
The existence of quasi-stationary alongshore atmospheric fronts typically located 30-70 km off the east coast of Taiwan is demonstrated by analyzing synthetic aperture radar (SAR) images of the sea surface acquired by the European Remote Sensing Satellites ERS-1 and ERS-2. For the data interpretation, cloud images from the Japanese Geostationary Meteorological Satellite GMS-4 and the American Terra satellite, rain-rate maps from ground-based weather radars, sea surface wind data from the scatterometer on board the Quick Scatterometer (QuikSCAT) satellite, and meteorological data from weather maps and radiosonde ascents have also been used. It is shown that these atmospheric fronts are generated by the collisions of the two airflows from opposing directions: one is associated with a weak easterly synoptic-scale wind blowing against the high coastal mountain range at the east coast of Taiwan and the other with a local offshore wind. At the convergence zone where both airflows collide, air is forced to move upward, which often gives rise to the formation of coast-parallel cloud bands. There are two hypotheses about the origin of the offshore wind. The first one is that it is a thermally driven land breeze/katabatic wind, and the second one is that it is wind resulting from recirculated airflow from the synoptic-scale onshore wind. Air blocked by the mountain range at low Froude numbers is recirculated and flows at low levels back offshore. Arguments in favor of and against the two hypotheses are presented. It is argued that both the recirculation of airflow and land breeze/katabatic wind contribute to the formation of the offshore atmospheric front but that land breeze/katabatic wind is probably the main cause.
\end{abstract}

\section{Introduction}

It is well known that atmospheric fronts over the ocean can be delineated on synthetic aperture radar (SAR) images. Since the radar backscattering over the ocean surface at oblique incidence angles is determined by the small-scale sea surface roughness (see, e.g., Valenzuela 1978), atmospheric fronts become visible on SAR images as boundaries between areas of differing sea surface roughness.

In the past, several investigations have been carried out for studying atmospheric fronts in the marine boundary layer by using SAR images acquired from

Corresponding author address: Dr. Werner Alpers, Zentrum für Meeres und Klimaforschung, Institut für Meereskunde, Universität Hamburg, Bundesstrasse 53, D-20146 Hamburg, Germany.

E-mail: alpers@ifm.uni-hamburg.de aircraft and satellites. They include synoptic-scale wind fronts (Ivanov et al. 2004; Young et al. 2005), land breeze fronts (Sikora et al. 1996; Winstead and Mourad 2000), and katabatic wind fronts (Alpers et al. 1998).

In this paper, we investigate alongshore coastal atmospheric fronts off the east coast of Taiwan by using SAR images of the sea surface acquired by the European Remote Sensing Satellites ERS-1 and ERS-2 in conjunction with data from other sensors. Sea surface manifestations of such fronts, which are located typically $30-70 \mathrm{~km}$ off the coast, are often visible on ERS SAR images acquired between 1023 and 1025 local standard time (LST). To verify that these frontal features are indeed sea surface manifestations of alongshore atmospheric fronts, we have compared them with satellite images of cloud distributions obtained from the Japanese Geostationary Meteorological Satellite GMS-4 and the American Terra satellite and with radar

DOI: 10.1175.JAS3863.1

(C) 2007 American Meteorological Society 
reflectivity maps (converted to rain-rate maps) obtained from ground-based weather radars. In addition, we have also used weather maps, radiosonde data, and sea surface wind data from the scatterometer onboard the Quick Scatterometer (QuikSCAT) satellite.

The motivation for this investigation has originated from our observation that on ERS SAR images acquired over the coastal waters east of Taiwan, often quite spectacular frontal features are visible. We have conjectured that the reason for this is the uniqueness of this coastal area; it is bordered to the west by a high mountain chain (average height: $1500 \mathrm{~m}$, maximum height: $3997 \mathrm{~m}$ ) and the coastal waters are quite warm because of the Kuroshio that flows adjacent to the coastline in a northward direction.

Previously, these frontal features visible on SAR images have sometimes been misinterpreted as being sea surface manifestations or "radar signatures" of the Kuroshio front (Hsu et al. 1997). Indeed, sea surface manifestations of atmospheric and oceanic fronts often look quite similar on SAR images; both types of fronts cause changes of the small-scale sea surface roughness and thus, via Bragg scattering (Valenzuela 1978), changes of the backscattered radar power. The small-scale sea surface roughness changes across an atmospheric front because of differing wind stress on both sides of the front. However, a variable surface current associated with an oceanic front can also modulate the small-scale sea surface roughness via hydrodynamic interaction. Usually it requires additional information to unambiguously identify frontal features visible on SAR images as atmospheric fronts, as is done in this investigation.

Quasi-stationary coastal fronts have been observed before in other parts of the world (Bosart et al. 1972; Bosart 1975; Roeloffzen et al. 1986; Oekland 1990; Huang 1993). Smolarkiewicz et al. (1988) have investigated cloud bands upwind of the island of Hawaii by using a numerical, small-scale, dynamical model (horizontal and vertical resolutions: $1 \mathrm{~km}$ and $62 \mathrm{~m}$, respectively). In this paper, we shall present arguments that the physical mechanism causing the generation of alongshore atmospheric fronts off the east coast of Taiwan is similar to the physical mechanism causing the generation of the cloud bands upwind of the island of Hawaii (Rasmussen et al. 1989; Rasmussen and Smolarkiewicz 1993).

As far as we know, no systematic investigations on coastal wind fields off the east coast of Taiwan have been carried out until now. However, numerical modeling of these wind fields is under way (W.-R. Hsu, NTU, 2005, personal communication). Recently, Yu and Jou (2005) have reported about observations of convective lines off the southeastern coast of Taiwan by using a ground-based C-band Doppler radar stationed on an island off the southeastern coast of Taiwan. Their data are confined to the period of 11-15 May 1998, which falls into the Taiwan Mei-yu season (Chen 1983). These authors argue that the convective lines result from the collision of a land-sea breeze front and synoptically prevailing airflow from the east.

This paper is organized as follows: in section 2 we present six representative examples of ERS SAR images showing sea surface manifestations of quasistationary atmospheric fronts off the east coast of Taiwan. In section 3 we summarize the observational facts based on the data presented in section 2 and on additional ERS SAR images not presented here because of space limitations. In section 4 we discuss the data in the light of models of the generation of atmospheric fronts. Finally, section 5 contains the conclusions.

\section{Case studies of atmospheric fronts}

For the case studies presented in this section, we have used ERS-1 and ERS-2 SAR images that were acquired over the east coast of Taiwan during descending satellite passes (satellite flight direction from north to south) between 0223 and 0225 UTC corresponding to 1023 and 1025 LST. During the descending paths, the SAR swath is located almost parallel to the east Taiwanese coastline. Its swath width is always $100 \mathrm{~km}$. Some $E R S-1$ and $E R S$-2 SAR images of the east coast of Taiwan were also acquired during ascending satellite passes (satellite flight direction from south to north) between 1416 and 1420 UTC corresponding to 2216 and 2220 LST. However, they do not cover the whole east coast of Taiwan and are not relevant for this investigation.

In the following, we present six examples of ERS SAR images showing sea surface manifestations of alongshore atmospheric fronts and compare them with other quasi-simultaneously acquired data. But there exist many more examples of ERS SAR images showing these atmospheric frontal features, for example, the ERS SAR images acquired on 19 November 1995, 24 November 1997, 9 November 1998, 22 February 1999, and 8 November 1999.

\section{a. The 18 January 1999 case}

The ERS-2 SAR image acquired at 0225 UTC (1025 LST) 18 January 1999 is depicted in Fig. 1. It shows a frontal line along the east coast of Taiwan at a distance approximately $50 \mathrm{~km}$ offshore. In the lower (southern) section, the image intensity, and thus the small-scale sea surface roughness, is strongly enhanced in the frontal zone because of flow convergence caused by opposing winds. The semicircular features with dark patches in 


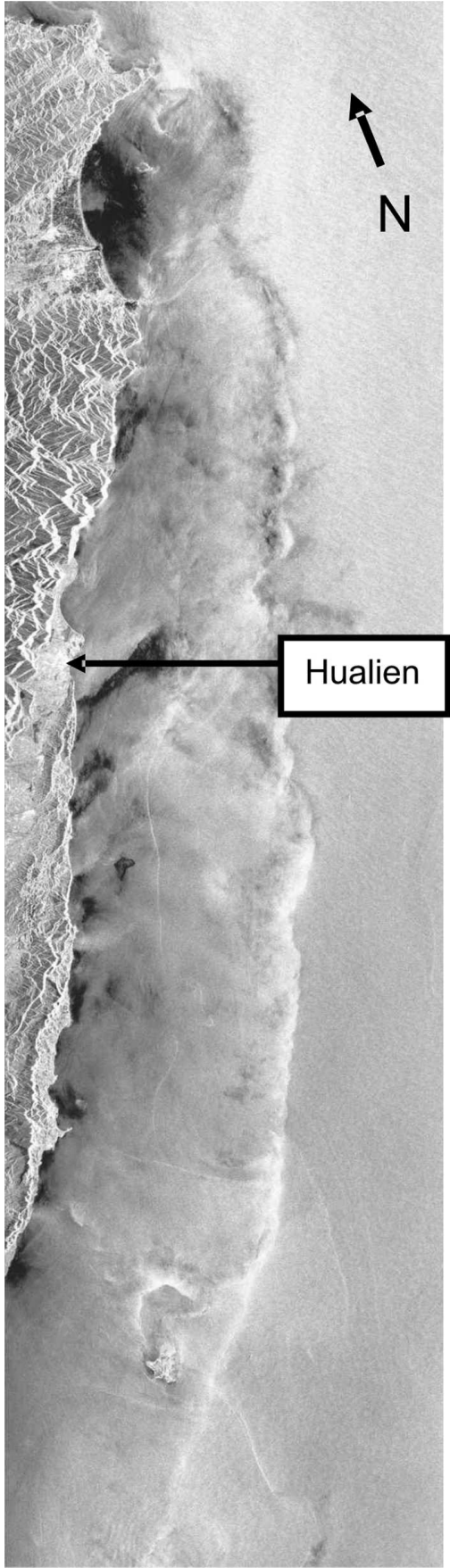

FIG. 1. ERS-2 SAR strip acquired at 0225 UTC (1025 LST) 18 Jan 1999 along the east coast of Taiwan. Imaged area is $380 \mathrm{~km} \times$ $100 \mathrm{~km}$. Courtesy of European Space Agency (ESA).

the center visible in the upper (northern) section of the image are sea surface manifestations of convective rain cells. Similar features are visible in the ERS SAR image (depicted in Fig. 4), where their interpretation as the sea surface manifestation of rain cells is proven by simultaneously acquired weather radar data.
The surface weather map at 0000 UTC 18 January 1999 shows that a weather station located on an island approximately $200 \mathrm{~km}$ east of Taiwan measured winds of $5 \mathrm{~m} \mathrm{~s}^{-1}$ from the southeast (SE; all directions will be abbreviated similarly throughout), cloud coverage of $7 / 8$, and rain showers. West of Taiwan, it shows winds of $2.5 \mathrm{~m} \mathrm{~s}^{-1}$ from the NNE.

The radiosonde launched at Hualien (a coastal town at the east coast of Taiwan; see Fig. 1) at 0000 UTC 18 January measured a wind speed of $2.6 \mathrm{~m} \mathrm{~s}^{-1}$ at a height of $19 \mathrm{~m}$ (the first radiosonde reading), a wind direction of $240^{\circ}$, an air temperature of $16.7^{\circ} \mathrm{C}$, and a relative humidity of $94 \%$. At heights between 413 and $2310 \mathrm{~m}$, the wind speed varied between 3.6 and $6.7 \mathrm{~m} \mathrm{~s}^{-1}$ and the wind direction between $203^{\circ}$ and $209^{\circ}$. Then the wind speed increased to $9.4 \mathrm{~m} \mathrm{~s}^{-1}$ at $3423 \mathrm{~m}$ where the wind direction was $237^{\circ}$, and to $19.4 \mathrm{~m} \mathrm{~s}^{-1}$ at $4677 \mathrm{~m}$ where the wind direction was $250^{\circ}$. The high relative humidity (varying between $86 \%$ and $100 \%$ ) was maintained from the ground up to a height of $4677 \mathrm{~m}$, above which it suddenly dropped to $37 \%$.

Figure 2 shows three cloud images taken from $G M S-4$ in the visible band. The upper image was taken only 8 min after the ERS-2 SAR data acquisition and shows a $60-\mathrm{km}$-wide cloud band adjacent to the east coast of Taiwan. Its eastern boundary follows closely the frontal line visible on the ERS-2 SAR image. The other two images were taken before and after that time at 0932 and 1532 LST, respectively. Also, these images show cloud bands parallel to the coastline.

The sequence of cloud images show that the distance from the cloud line to the coast varied with time. At 0932 LST, the cloud line was located approximately 20 $\mathrm{km}$ off the coast, at 1033 it was $60 \mathrm{~km}$, at 1133 it was 45 $\mathrm{km}$, at 1332 it was $60 \mathrm{~km}$, and at 1637 it was $40 \mathrm{~km}$ off the coast. Cloud lines can serve as tracers of atmospheric fronts only when the moisture content is such that it allows the formation of clouds and when the sky is not completely cloud covered. This was the case on 18 January 1999.

Since the water temperature of the Kuroshio (around $25^{\circ} \mathrm{C}$ in January) was much higher than the air temperature $\left(16.7^{\circ} \mathrm{C}\right)$, the air-sea interface near the coast was highly unstable. This gave rise to strong turbulence and thus to the enhanced generation of short-scale waves as well as to an inhomogeneous short-scale wave field, causing the inhomogeneous texture in the SAR image.

\section{b. The 7 April 1996 case}

The ERS-1 SAR image acquired at 0225 UTC (1025 LST) 7 April 1996 is depicted in Fig. 3. It shows a frontal line along the east coast of Taiwan at a distance 
(a)

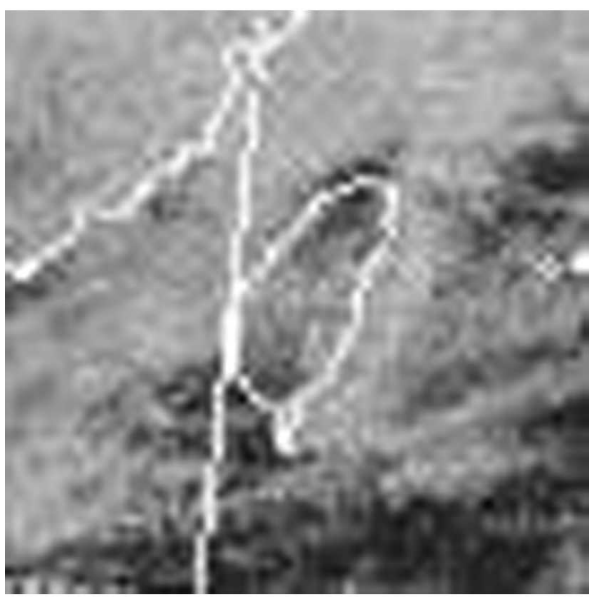

(b)

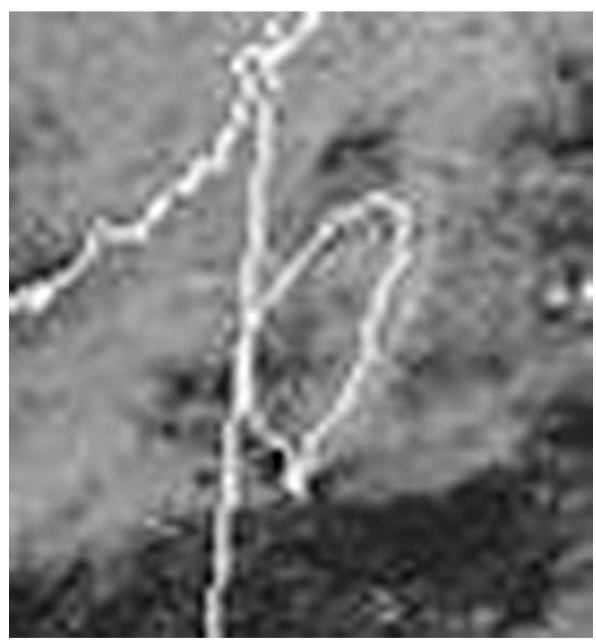

(c)

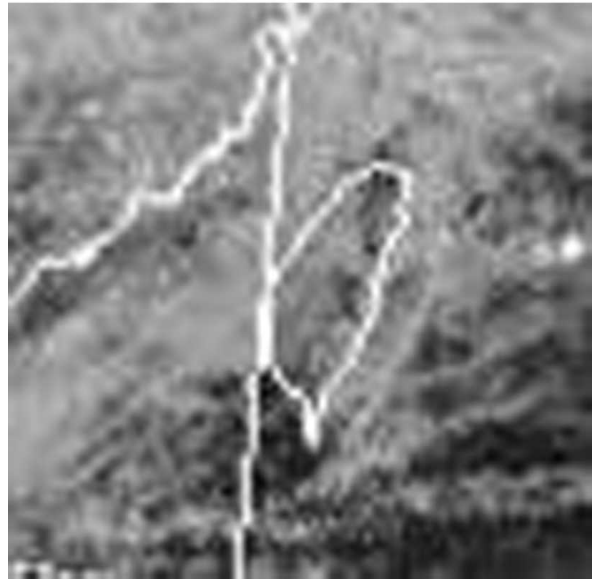

FIG. 2. Cloud images acquired by GMS-4 in the visible band at (top) 0233 (1033 LST), (middle) 0132 (0932 LST), and (bottom) 0533 UTC (1333 LST) 18 Jan 1999.

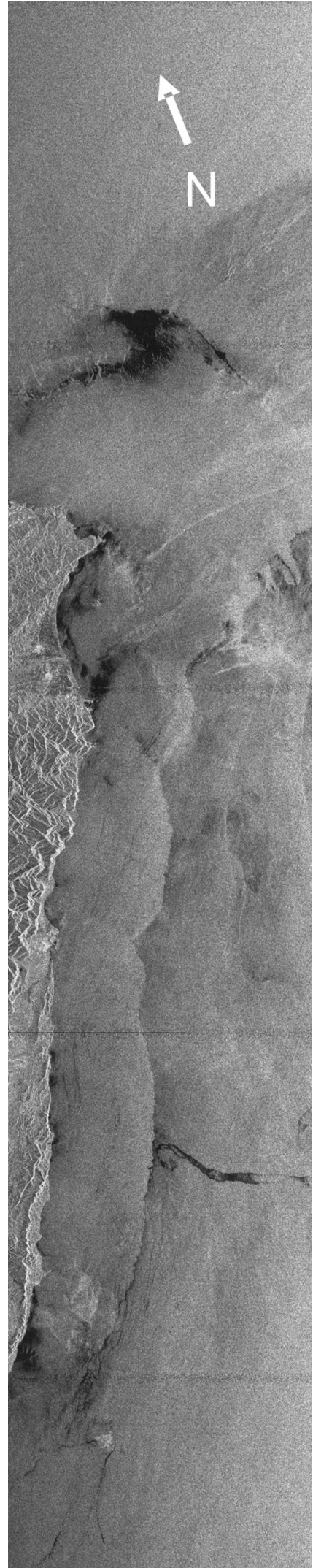

FIG. 3. ERS-1 SAR strip acquired at 0225 UTC (1025 LST) 7 Apr 1996 along the east coast of Taiwan. Imaged area is $540 \mathrm{~km} \times 100 \mathrm{~km}$. Courtesy of ESA. 
of approximately $30 \mathrm{~km}$ offshore. When comparing this SAR image with the SAR image depicted in Fig. 1, one notes that the roughness band parallel to the coast has a much more homogeneous texture. This can be explained by the fact that on this day, the air temperature was only slightly lower than the sea surface temperature. Therefore, the air-sea interface was only slightly unstable or neutrally stable, such that no turbulence was generated. Note the curved dark line in the lower section of the image that is apparently the radar signature of a ship-generated oil spill. It is deflected eastward, which suggests that it is caused by an offshore surface wind.

The surface weather map of 0000 UTC 7 April 1996 shows winds of $2.5 \mathrm{~m} \mathrm{~s}^{-1}$ from the $\mathrm{SE}$ and altocumulus clouds approximately $200 \mathrm{~km}$ east of Taiwan. Furthermore, it shows that at the weather station at Taitung (a coastal town located at the southern section of the east coast of Taiwan), the lower cloud level was between 600 and $1000 \mathrm{~m}$. This implies that the clouds near the coast and over the open ocean must have been of a different origin, that is, the clouds near the coast must have been generated locally.

The radiosonde launched at Hualien at 0000 UTC 7 April 1996 measured at a height of $152 \mathrm{~m}$ a wind speed of $1.1 \mathrm{~m} \mathrm{~s}^{-1}$, a wind direction of $251^{\circ}$, an air temperature of $21.1^{\circ} \mathrm{C}$, and a relative humidity of $98 \%$. At heights between 825 and $1577 \mathrm{~m}$, the wind speed varied between 1.1 and $1.6 \mathrm{~m} \mathrm{~s}^{-1}$ and the wind direction varied between $185^{\circ}$ and $195^{\circ}$. (Note, however, that the accuracy of wind direction measurements is very poor when the wind speed is less than $2 \mathrm{~m} \mathrm{~s}^{-1}$.) Above this height the wind veered into a westerly direction and had at a height of $3821 \mathrm{~m}$ a wind speed of $7.8 \mathrm{~m} \mathrm{~s}^{-1}$ and a wind direction of $274^{\circ}$.

The GMS-4 cloud image acquired at 0201 UTC (1001 LST; i.e., 24 min before the ERS-2 SAR data acquisition) 7 April 1996, which is depicted in Fig. 4, also shows a cloud band adjacent to the east coast of Taiwan. Its eastern boundary follows closely the frontal line visible on the ERS-1 SAR image.

\section{c. The 7 January 2002 case}

The ERS-2 SAR image acquired at 0225 UTC (1025 LST) 7 January 2002 is depicted in Fig. 5. It shows a broad ragged frontal feature off the coast with embedded dark patches that extends from the center of the image southward. We interpret the dark patches as being sea surface manifestations of rain cells. Evidence for this interpretation is provided by the quasisimultaneously acquired weather radar image (depicted in Fig. 8). In the lower right-hand side of the SAR image, wind streaks are visible, which are oriented in a

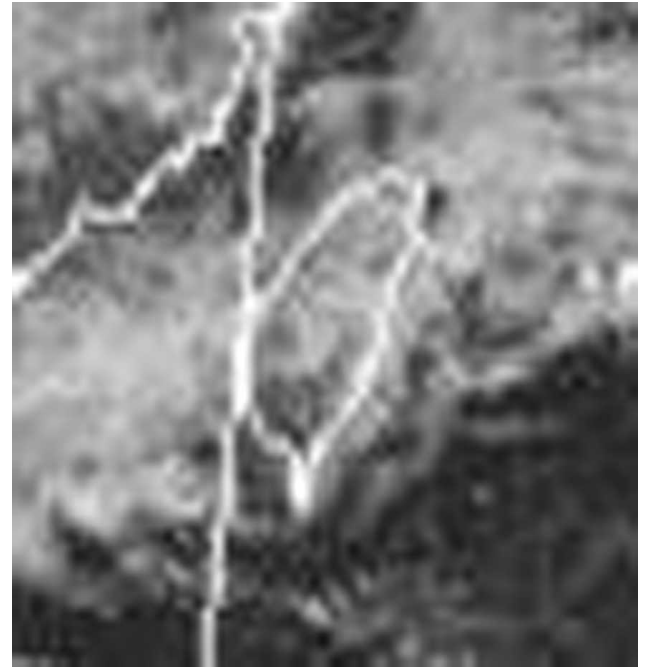

FIG. 4. Cloud image acquired by $G M S-4$ in the visible band at 0201 UTC (1001 LST) 7 Apr 1996.

NW-SE direction. This indicates that the wind was blowing there from the SE, which is consistent with the wind direction measured by QuikSCAT $4 \mathrm{~h} 25$ min earlier (see Fig. 7). Note also the elongated dark patches adjacent to the coastline that result from wind shadowing. This indicates that an offshore wind was blowing from the coastal mountains onto the sea.

The radiosonde launched at Hualien at 0000 UTC 7 January 2002 measured at a height of $19 \mathrm{~m}$, a wind speed of $4.2 \mathrm{~m} \mathrm{~s}^{-1}$, a wind direction of $240^{\circ}$, an air temperature of $16.0^{\circ} \mathrm{C}$, and a relative humidity of $78 \%$. At heights between 432 and $1149 \mathrm{~m}$, the wind speed varied between 2.2 and $1.0 \mathrm{~m} \mathrm{~s}^{-1}$ and the wind direction between $22^{\circ}$ and $62^{\circ}$. (Note, however, that the wind direction can be erroneous because of the low wind speed.) Above this height, the wind veered into a westerly direction. At a height of $3516 \mathrm{~m}$, it had a wind speed of $9.1 \mathrm{~m} \mathrm{~s}^{-1}$ and a wind direction of $290^{\circ}$.

The cloud images acquired 45 min later by the Moderate Resolution Imaging Spectroradiometer (MODIS) sensor onboard Terra are depicted in Fig. 6. This image and also the cloud image acquired only 7 min later by GMS-4 (not shown here) show clouds east of Taiwan that are separated from the coastline by a cloud-free area. The absence of clouds near the coast suggests that the descending air along the mountain range, which is warmer (because of adiabatic warming) and thus drier than the surrounding air, has replaced the moist air and has blown away the clouds. The sequence of hourly GMS-4 cloud images acquired in the visible band reveals that this cloud-free band persisted during the whole day and was also present the day before. The sequences of GMS-4 cloud images acquired in the in- 


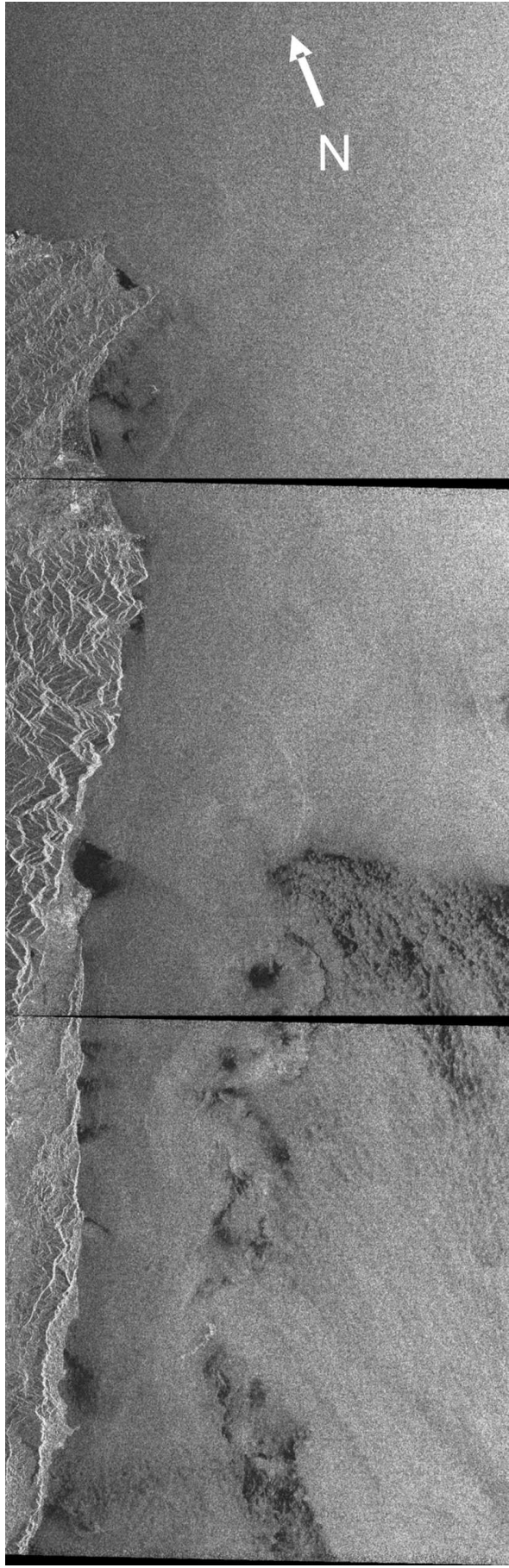

FIG. 5. ERS-2 SAR strip acquired at 0225 UTC (1025 LST) 7 Jan 2002 along the east coast of Taiwan. Imaged area is $330 \mathrm{~km} \times$ $100 \mathrm{~km}$. Courtesy of ESA.

frared bands on 6 and 7 January 2002 reveal that highlevel clouds coming from a westerly direction were blown over Taiwan. These clouds, unaffected by the mountain chain, were clouds associated with a cold front of a cyclone centered over the Sea of Japan.

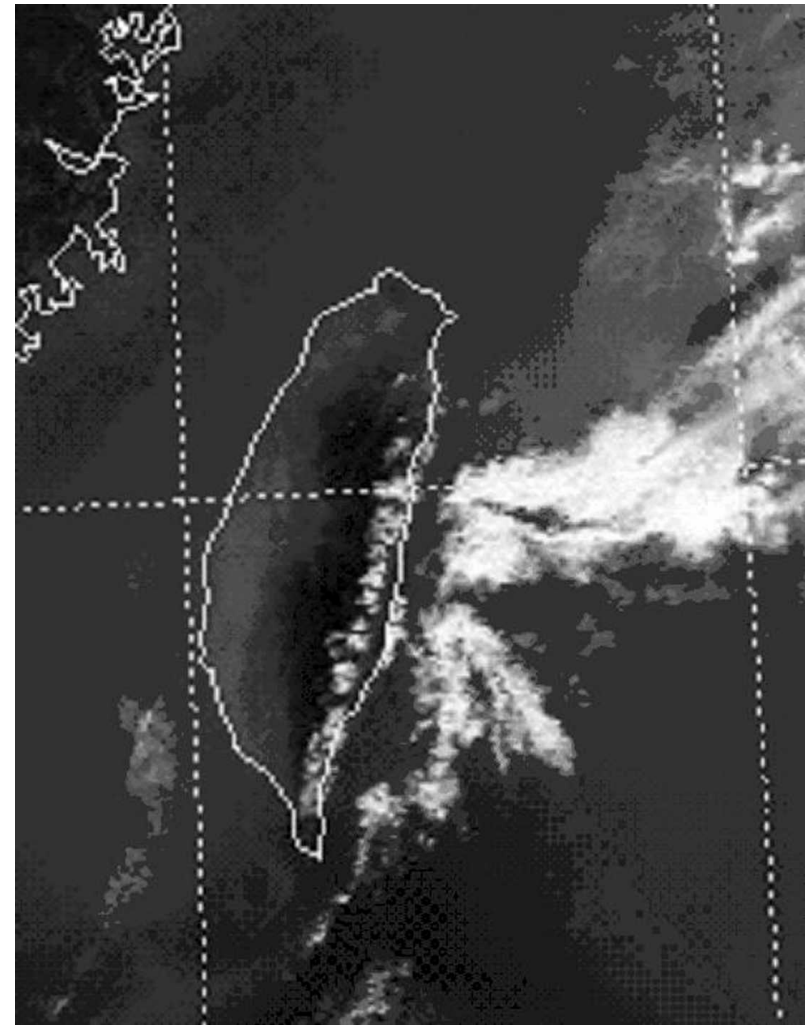

FIG. 6. MODIS cloud image acquired at 0310 UTC (1110 LST) 7 Jan 2002 over Taiwan and the adjacent area.

On 7 January 2002, measurements of the sea surface wind field were carried by the scatterometer onboard QuikSCAT (spatial resolution: $25 \mathrm{~km}$ ) at 0542 and 1806 LST. The wind field measured at 0542 LST is depicted in Fig. 7. Note that QuikSCAT cannot measure sea surface wind fields close to the coast because of contamination by radar backscatter from land. This map shows that $4 \mathrm{~h}$ and $43 \mathrm{~min}$ before the SAR data acquisition, the wind was blowing in the southern section of the coastal waters with a speed of 4-6 $\mathrm{m} \mathrm{s}^{-1}$ from an easterly direction and farther north with a speed of $10-14 \mathrm{~m} \mathrm{~s}^{-1}$ from a northwesterly direction. The wind field map from QuikSCAT at 1806 LST (not reproduced here) shows that at this time, the wind was blowing in the whole coastal region with an almost uniform speed of $10-14 \mathrm{~m} \mathrm{~s}^{-1}$ from a northerly direction. We interpret the absence of a visible atmospheric front in the northern section on the ERS SAR image as being caused by the strong synoptic-scale wind, which prevents the generation of an atmospheric front.

For this event, simultaneously acquired weather radar data are also available. Weather radar images are acquired every $30 \mathrm{~min}$ by Taiwanese weather radar stations and are archived by the Central Weather Bureau 


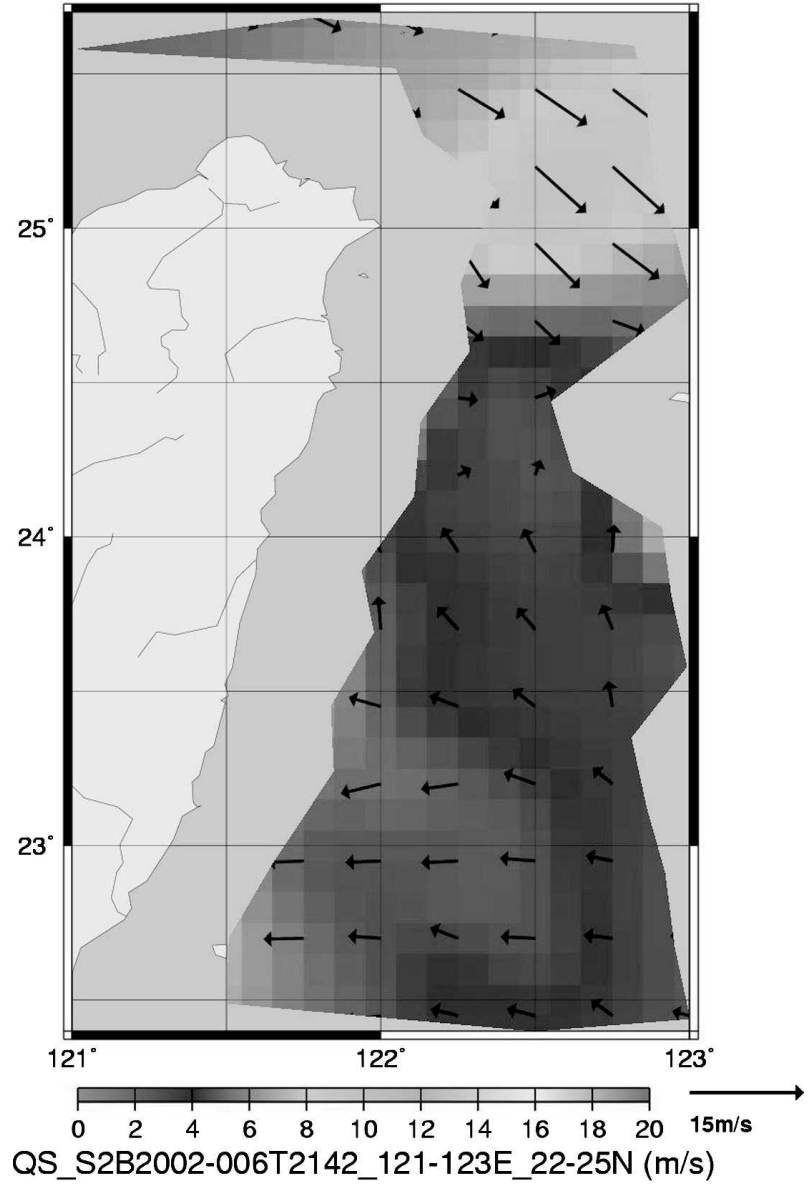

FIG. 7. QuikSCAT wind field map derived from data acquired at 2142 UTC 6 Jan 2002 (0542 LST 7 Jan).

of Taiwan since 2002. Figure 8 shows a weather radar image acquired at 0230 UTC 7 January, that is, $6 \mathrm{~min}$ later than the ERS-2 SAR image acquisition. The comparison of this weather radar image with the SAR image (Fig. 5) shows a fairly good correspondence of the rain cells with the sea surface manifestations of rain cells. The weather radar image shows a rainband approximately at the location where sea surface signatures of rain cells are visible on the ERS-2 SAR image. Note, however, that the correspondence is not exact because of the fact that 1) the images were not acquired at the same time and 2) the weather radar measures raindrops in the atmosphere, while the SAR measures rain at the sea surface via changes of the small-scale sea surface roughness caused by the rain drops impinging on the sea surface and by wind downdrafts associated with the rain cells (see, e.g., Melsheimer et al. 2001).

\section{d. The 3 May 1999 case}

The ERS-2 SAR image acquired at 0225 UTC (1025 LST) 3 May 1999 is depicted in Fig. 9. It shows a frontal line along the east coast of Taiwan at a distance of approximately $70 \mathrm{~km}$ offshore. On the average, the 70$\mathrm{km}$-wide frontal band exhibits a lower radar backscatter than the sea area farther east.

The surface weather map of 0000 UTC 3 May 1999 east of Taiwan shows winds of $5 \mathrm{~m} \mathrm{~s}^{-1}$ from an easterly direction and $7 / 8$ cloud cover [2/8 of the clouds were low-level cumulus clouds (300-600 m above sea level) and $5 / 8$ of them were high clouds]. At the coast, the air temperature was $27^{\circ} \mathrm{C}$, which was higher than the sea surface temperature.

The radiosonde launched at Hualien at 0000 UTC 3 May 1999 measured at a height of $19 \mathrm{~m}$ a wind speed of $1.6 \mathrm{~m} \mathrm{~s}^{-1}$, a wind direction of $260^{\circ}$, an air temperature of $20.8^{\circ} \mathrm{C}$, and a relative humidity of $99 \%$. At heights between 796 and $2035 \mathrm{~m}$, the wind speed varied between 4.8 and $7.4 \mathrm{~m} \mathrm{~s}^{-1}$ and the wind direction between $212^{\circ}$ and $194^{\circ}$. The winds farther up veered in a westerly direction. At a height of $3923 \mathrm{~m}$, the wind speed was $11.8 \mathrm{~m} \mathrm{~s}^{-1}$ and the wind direction was $234^{\circ}$.

The cloud image acquired $7 \mathrm{~min}$ later by $G M S-4$ at 1032 LST (not reproduced here) shows a cloud cover of approximately $80 \%$ in the area imaged by the SAR and a very distinct line of dense clouds closely following the frontal line. We interpret this as being caused by moist air coming from the east that is lifted upward when it collides with the air from the mountains. The sequences of GMS-4 cloud images acquired in the infrared bands on 2 and 3 May 1999 reveal that high-level clouds were blown from the west over Taiwan where they were not affected by the Central Mountain Range.

\section{e. The 23 April 1995 case}

The ERS-2 SAR image acquired at 0225 UTC (1025 LST) 23 April 1995 depicted in Fig. 10 shows in the central section adjacent to the coast a dark area that to the east is confined by a frontal line running along the coast at a distance of approximately $50 \mathrm{~km}$ offshore. Some of the features visible at the most northern and southern sections of the front are of oceanic origin and result from the interaction of the Kuroshio with shallow bottom topography and islands.

The gray levels in the SAR image on both sides of the front are quite similar, with the exception of the large dark patch in the center. This dark patch is caused either by the presence of surfactants floating on the sea surface or by low wind whose speed is below the threshold (2-3 $\mathrm{m} \mathrm{s}^{-1}$ ) for short-wave (Bragg wave) generation.

The surface weather map of 0000 UTC 23 April 1995 shows winds of $5 \mathrm{~m} \mathrm{~s}^{-1}$ from SW east of Taiwan and winds of $2.5 \mathrm{~m} \mathrm{~s}^{-1}$ from SW west of Taiwan. The radiosonde launched at Hualien at 0000 UTC 23 April 


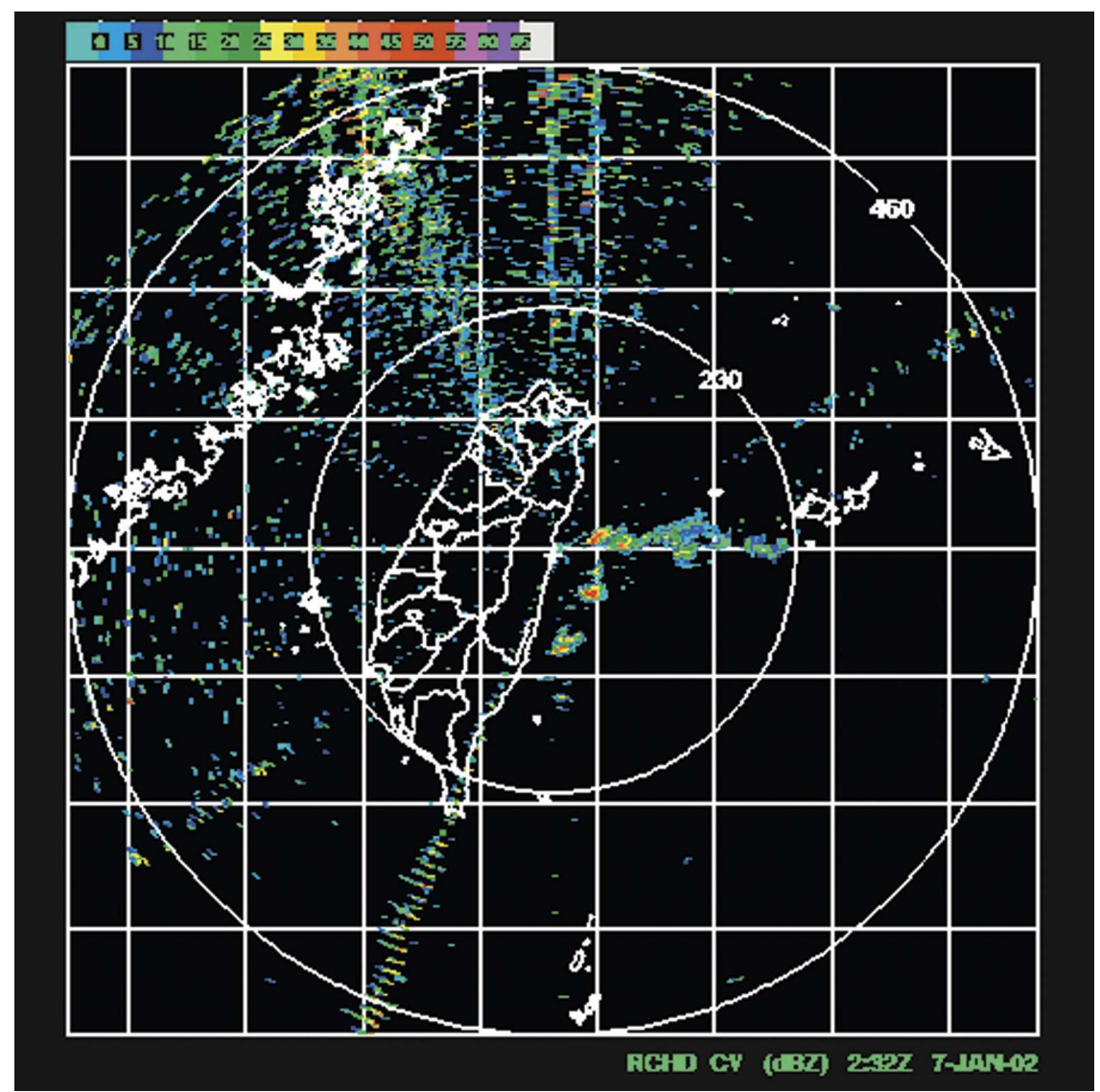

FIG. 8. Weather radar image acquired at 0232 UTC (1032 LST) 7 Jan 2002.

measured at a height of $19 \mathrm{~m}$ a wind speed of $1.1 \mathrm{~m} \mathrm{~s}^{-1}$, a wind direction of $240^{\circ}$, an air temperature of $24.4^{\circ} \mathrm{C}$, and a relative humidity of $67 \%$. At heights between 102 and $912 \mathrm{~m}$, the wind speed varied between 1.7 and 3.8 $\mathrm{m} \mathrm{s}^{-1}$ and the wind direction between $206^{\circ}$ and $168^{\circ}$. At a height of around $1400 \mathrm{~m}$ there was an inversion layer. Below this height the relative humidity was $88 \%$ and above it was $22 \%$. Also on this day, a westerly wind was blowing at higher levels (for example, at $3169 \mathrm{~m}$, the wind speed was $3.0 \mathrm{~m} \mathrm{~s}^{-1}$ and the wind direction $288^{\circ}$ ).

Figure 11 shows a National Oceanographic and Atmospheric Administration (NOAA) NOAA-9 Advanced Very High Resolution Radiometer (AVHRR) infrared image (channel 4) of the waters surrounding Taiwan at 0113 UTC 24 April 1995 [0913 LST; i.e., 22 h and 48 min later than the ERS SAR image but at approximately the same time of the day $(1 \mathrm{~h}$ and $12 \mathrm{~min}$ earlier)]. Unfortunately, no AVHRR image is available for 23 April. The weather conditions on 24 and 23 April were quite similar. A cloud band that is located at approximately the same position as the front on the $E R S$-1 SAR image is visible. This is a clear indication that the front visible on the ERS-1 SAR image is of atmospheric origin. Note that the cloud band closely follows the coastline, which is a clear indication that it has its origin in an interaction of the atmosphere with the island. On both days the sky was almost cloud free such that the low-land coastal areas could be heated up by solar radiation. Evidence of this is also provided by the infrared image depicted in Fig. 11.

If we assume that the meteorological conditions were the same on 23 and 24 April, then we may infer from the radiosonde data that the clouds visible on the AVHRR image are cumulus clouds with an upper cloud height of $1400 \mathrm{~m}$ (the height of the inversion layer) that have been generated by the ascent of moist air at the frontal line.

\section{f. The 16 May 2005 case}

The ERS-2 SAR image acquired at 0224 UTC (1024 LST) 16 May 2005 is depicted in Fig. 12. It shows a quite ragged frontal line along the east coast of Taiwan with an average offshore distance of approximately 30 $\mathrm{km}$. The frontal feature visible on this SAR image is located closer to the coastline than in the other cases. We attribute this to the stronger synoptic-scale onshore 


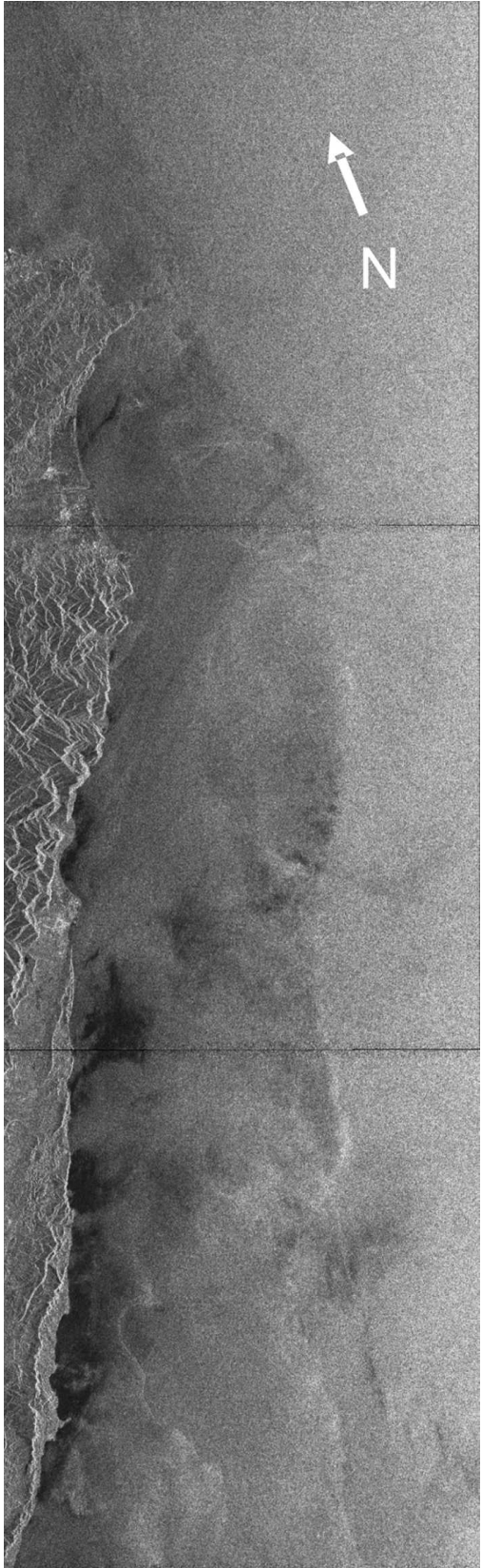

FIG. 9. ERS-2 SAR strip acquired at 0225 UTC (1025 LST) 3 May 1999 along the east coast of Taiwan. Imaged area is $300 \mathrm{~km} \times 100 \mathrm{~km}$. Courtesy of ESA.

wind as evidenced by the QuikSCAT data (see Fig. 13). The dark patches embedded in the frontal area are sea surface manifestations of rain cells as evidenced by the weather radar image depicted in Fig. 14. The dark areas in the northern section of the image are either areas of low wind speed or areas covered with (natural) surfactants where the sea surface is smooth.

The surface weather map of 0000 UTC 16 May 2005 east of Taiwan shows winds of $5 \mathrm{~m} \mathrm{~s}^{-1}$ from an easterly

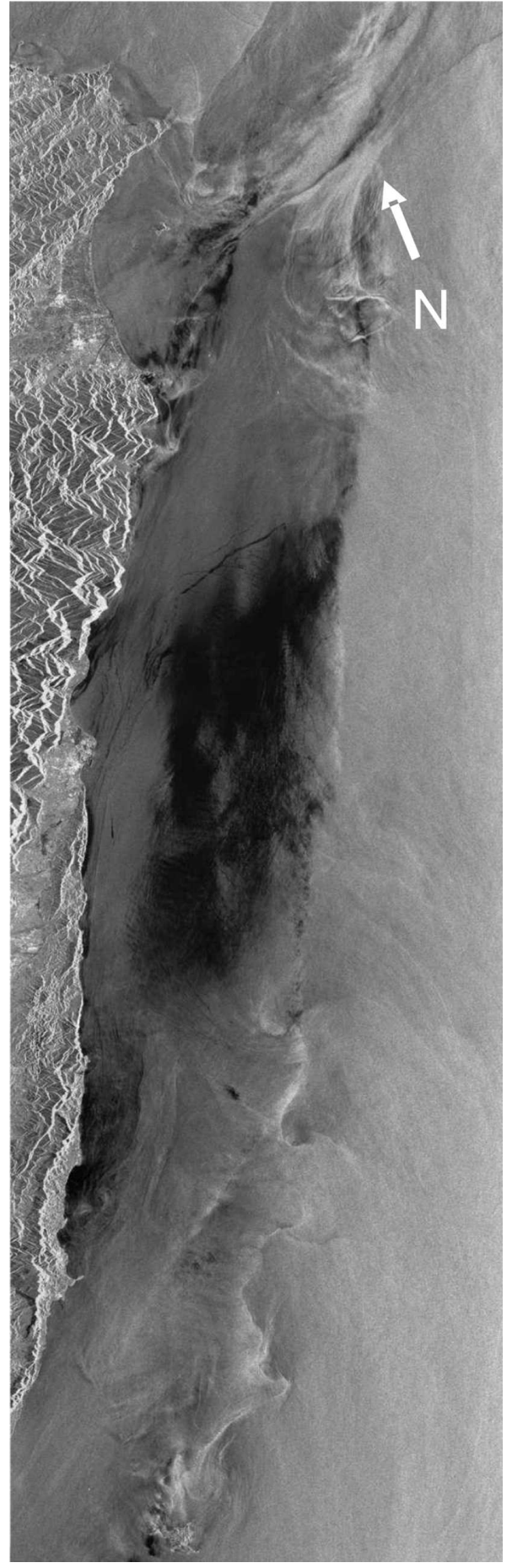

FIG. 10. ERS-2 SAR strip acquired at 0225 UTC (1025 LST) 23 Apr 1995 along the east coast of Taiwan. Imaged area is $330 \mathrm{~km} \times 100 \mathrm{~km}$. Courtesy of ESA.

direction. The radiosonde launched at Hualien at 0000 UTC 16 May 2005 measured at a height of $19 \mathrm{~m}$ a wind speed of $0.1 \mathrm{~m} \mathrm{~s}^{-1}$, a wind direction of $36^{\circ}$, an air temperature of $25.1^{\circ} \mathrm{C}$, and a relative humidity of $90 \%$. 


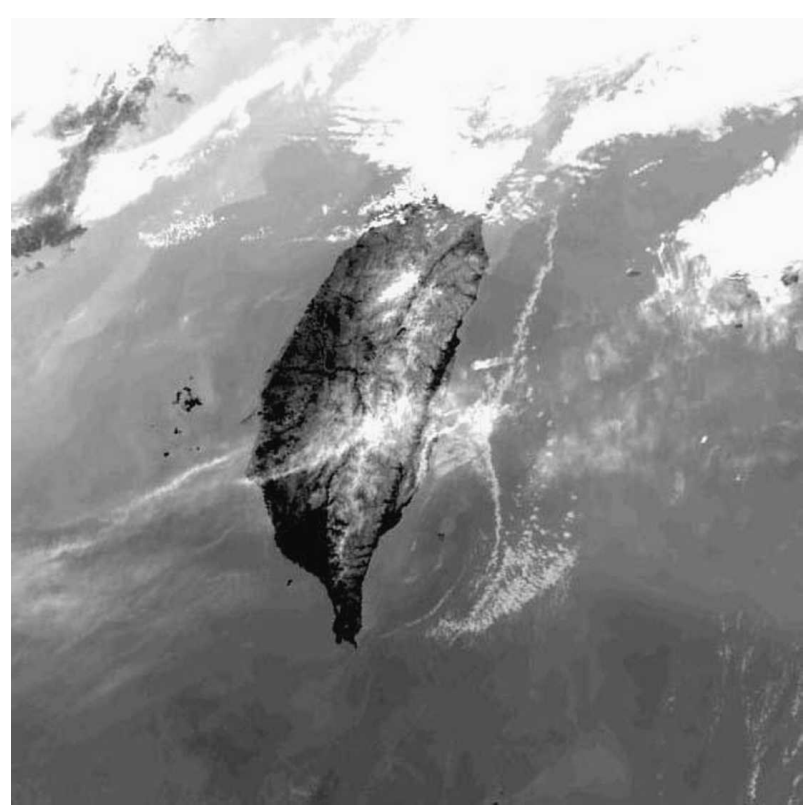

FIG. 11. NOAA-9 AVHRR infrared image (channel 4) acquired at 0113 UTC (0913 LST) 24 Apr 1995 of the waters surrounding Taiwan.

Between 788 and $2053 \mathrm{~m}$, the wind speed varied between 1.5 and $3.9 \mathrm{~m} \mathrm{~s}^{-1}$ and the wind direction between $156^{\circ}$ and $227^{\circ}$. Above it, the wind veered in a westerly direction (e.g., at a height of $3166 \mathrm{~m}$, the wind speed was $8.4 \mathrm{~m} \mathrm{~s}^{-1}$ and the wind direction was $307^{\circ}$ ).

The sea surface wind field measured by QuikSCAT at 2142 UTC 15 May (i.e., $4 \mathrm{~h}$ and 42 min before the ERS-2 SAR data acquisition) is depicted in Fig. 13. It shows an easterly wind of $6 \mathrm{~m} \mathrm{~s}^{-1}$ in most parts off the east coast of Taiwan, and a wind speed of $8.5 \mathrm{~m} \mathrm{~s}^{-1}$ in the central part close to the coast.

For this case, simultaneously acquired weather radar data are available. Figure 14 shows a weather radar image acquired at 0230 UTC (1030 LST) 16 May, that is, 6 min later than the SAR image acquisition. The comparison of the position of the rain cells (the red areas) visible on this weather radar image with the position of the sea surface manifestations of the rain cells visible on the SAR image (Fig. 12) shows fairly good agreement. In Fig. 15, a weather radar image is shown that was acquired at 1600 UTC 15 May (0000 LST 16 May). It shows a quite narrow rainband close to the coast at midnight, which later in the night broadened and moved farther away from the coast.

\section{Summary of observations}

From the analysis of ERS SAR images acquired over the east coast of Taiwan around 1025 LST in conjunc-

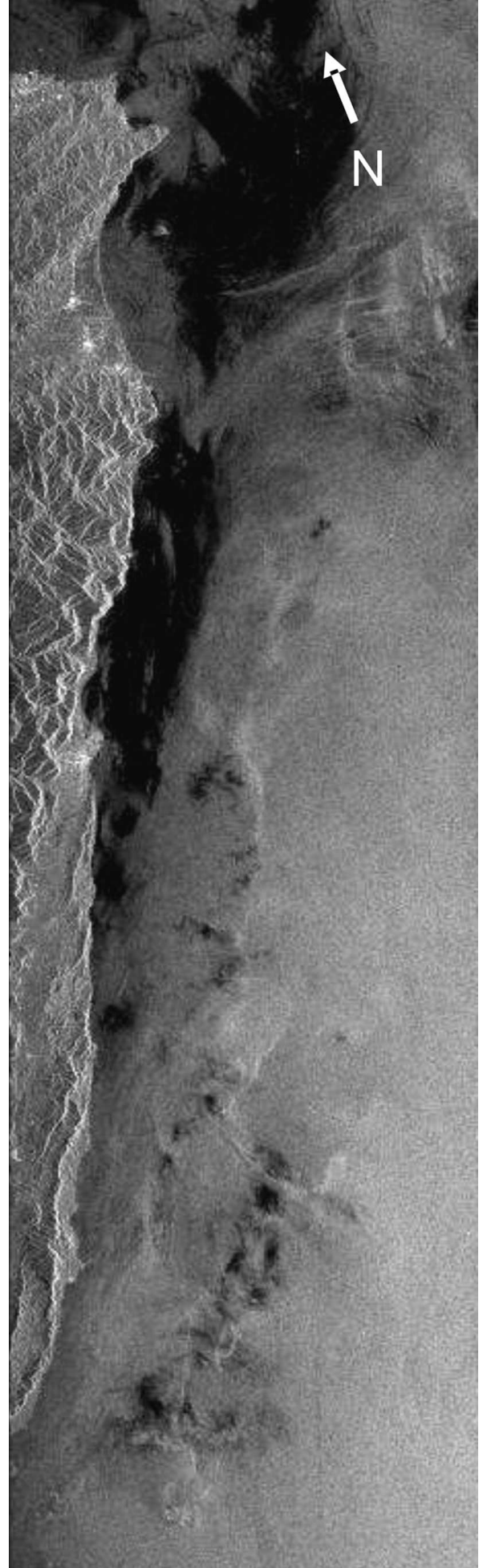

FIG. 12. ERS-2 SAR strip acquired at 0224 UTC (1024 LST) 16 May 2005 along the east coast of Taiwan. Imaged area is $350 \mathrm{~km} \times 100 \mathrm{~km}$. Courtesy of ESA. 


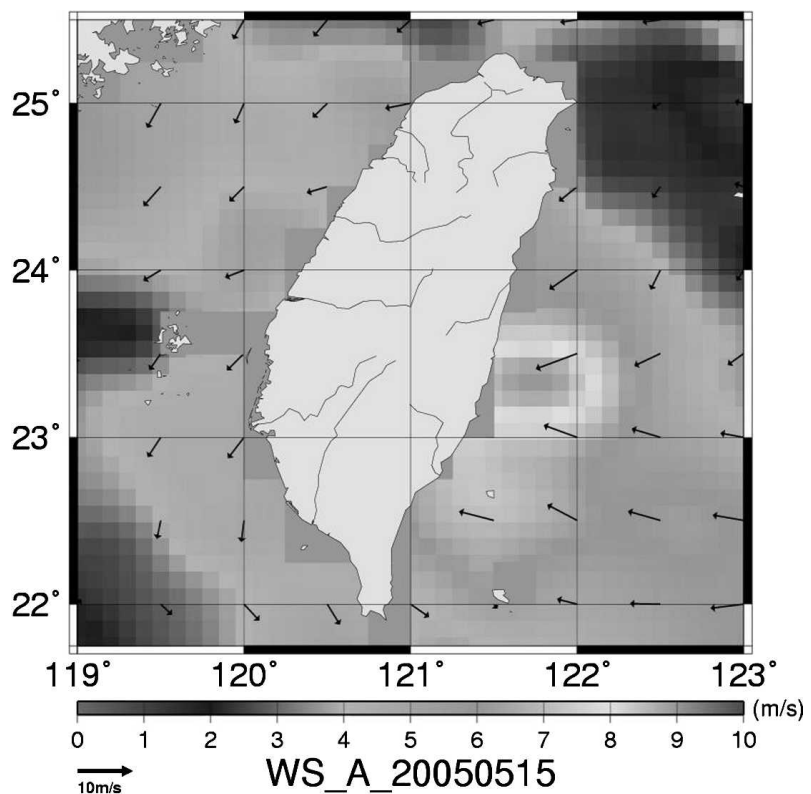

FIG. 13. QuikSCAT wind field map from data acquired at 2142 UTC 15 May 2005 (0542 LST 16 May).

tion with other data described in the text, we obtain the following observational results:

1) Alongshore atmospheric fronts off the east coast of Taiwan are observed when a weak easterly synopticscale wind with an onshore speed around 2.5-5 $\mathrm{m} \mathrm{s}^{-1}$ is blowing against the mountain chain. In this case, the Froude number is around 0.1-0.2.

2) Their distance from the coastline lies between 30 and $70 \mathrm{~km}$.

3) Strong alongshore atmospheric fronts have been detected only between November and May in which a northeasterly wind prevails due to the monsoon. We also suspect that the high sea surface temperature of the Kuroshio plays an important role in the formation of the alongshore atmospheric front. The large air-sea temperature difference in these months gives rise to a turbulent boundary layer near the coast.

4) The quasi-stationary fronts are often associated either with (i) a cloud boundary separating cloudcovered and cloud-free areas, (ii) a cloud line, or (iii) a line of increased cloud density.

5) The ERS SAR images often show sea surface manifestations of rain cells imbedded in the fronts. In two cases we have been able to confirm this by quasisimultaneously acquired weather radar images.

6) Time series of cloud images show that the atmospheric fronts persist at least from early morning to afternoon. In the morning, the cloud bands are usu- ally located closer to the shoreline. In the afternoon, the cloud bands often dissolve.

7) The radiosonde data from Hualien show that the depth of the layer where the airflow is directed offshore is less than $825 \mathrm{~m}$. Above this height but below the height of the mountain range, the airflow is directed mostly in a northward or a southward direction parallel to the mountain range. Above the height of the mountain range, the wind blows from a westerly direction and usually increases with height.

8) The width of the frontal zone is typically $1-5 \mathrm{~km}$.

\section{Theoretical interpretation}

The crucial question to be answered is as follows: what is the origin of the offshore airflow colliding with the synoptic-scale wind?

We have discarded the hypothesis that winds blowing from the west over the mountain range (Foehn-type winds) are responsible for the front formation. This would require the lifting of low-level air over the high mountain range (average height: $2500 \mathrm{~m}$ ), which is only possible when the Froude number is sufficiently large (above 1). This requires high low-level winds at the west side of the mountain range, which are not observed.

We have also discarded the hypothesis that the front is caused by a barrier wind or a barrier jet. This wind system can develop only when a strong wind blows against the mountain range and when the path of the airflow is long enough such that the Coriolis force can act on the flow. In this case, the direction of the coastal wind should be to the south and parallel to the coastline. But this is not observed. Furthermore, we have observed the fronts only in the presence of weak onshore winds.

Thus we are left with the following remaining hypotheses: the offshore airflow colliding with the onshore airflow of the synoptic-scale wind originates from 1) the recirculation of air blocked by the mountain range, 2) land breeze/katabatic wind, or 3) a combination of both wind systems.

\section{a. Recirculation of air blocked by the mountain range}

One possible source of the offshore wind is the recirculation of air reflected from the mountain range. Thus, a recirculation cell or roll is formed on the windward side of the mountain range. This mechanism has been studied in detail with computer simulations by 


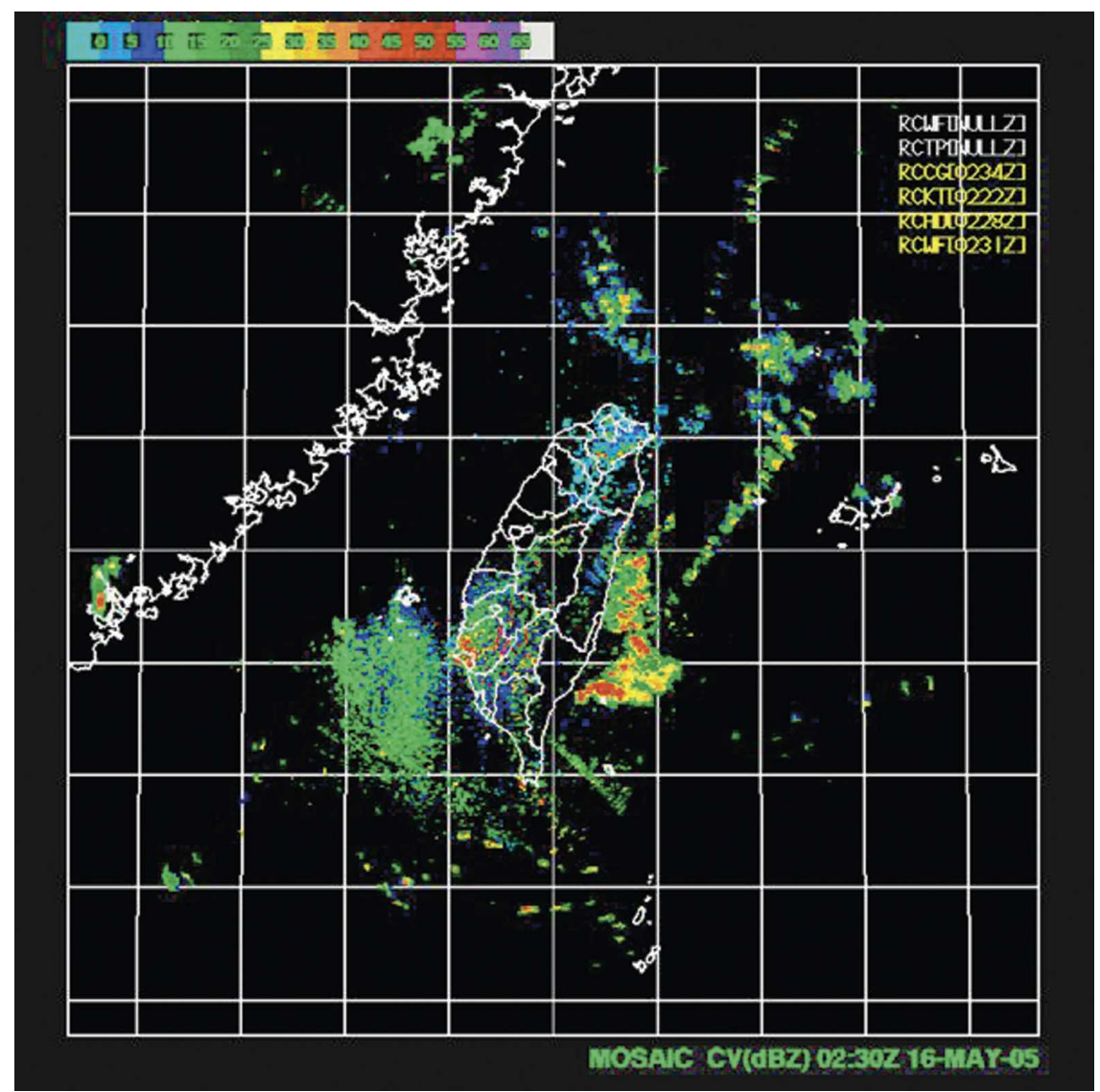

FIG. 14. Weather radar image acquired at 0230 UTC (1030 LST) 16 May 2005.

Smolarkiewicz et al. (1988) and compared with observations of cloud bands off the Hawaiian Islands, where they found good agreement between theory and observations. Several arguments can be put forward that such a mechanism also applies in our case.

In all cases analyzed in our study, a synoptic-scale easterly (onshore) wind was blowing at low levels and a westerly (offshore) wind at high levels. The radiosonde at Hualien measured in all cases at lower levels (up to heights between 102 and $825 \mathrm{~m}$ ) an offshore wind component between 1 and $3 \mathrm{~m} \mathrm{~s}^{-1}$. Therefore a reasonable estimate for the depth of the outflow layer is a value around $500 \mathrm{~m}$. At heights above $500 \mathrm{~m}$ but below the height of the mountain range, the wind direction was mostly alongshore, either from the north or south. However, these measured wind directions could be erroneous because of the low wind speed.

A schematic plot showing the airflow system where the offshore airflow is caused by the recirculation of air reflected from the mountain range is depicted in Fig. 16. When impinging on the mountain range, the synoptic airflow splits in two vertical directions. The down- ward part forms the return flow, whereas the upward part climbs up the mountains and forms clouds. If it were purely a land-sea breeze generating the front, the air would flow down along the mountain slope and no clouds would be formed inland at the coast (see Fig. 6).

It is important to realize that the frontal lines visible on the ERS SAR images are sea surface manifestations of near-surface wind fronts that are not necessarily located below alongshore cloud or rainbands. Rasmussen et al. (1989) found in their model runs that cloud bands form intermittently. They are generated over the main updraft, tend to move with the mean cloud layer winds, and dissipate rapidly after moving away from the lowlevel forcing region. Thus, the often observed absence of coastal cloud bands in the afternoon and in the evening does not necessarily imply the absence of an atmospheric front. It could be that solar heating causes dissipation of the cloud bands later during the day. Another mechanism for cloud band formation mentioned by these authors is the migration of preexisting convective clouds into the convective frontal zone where they intensify. 


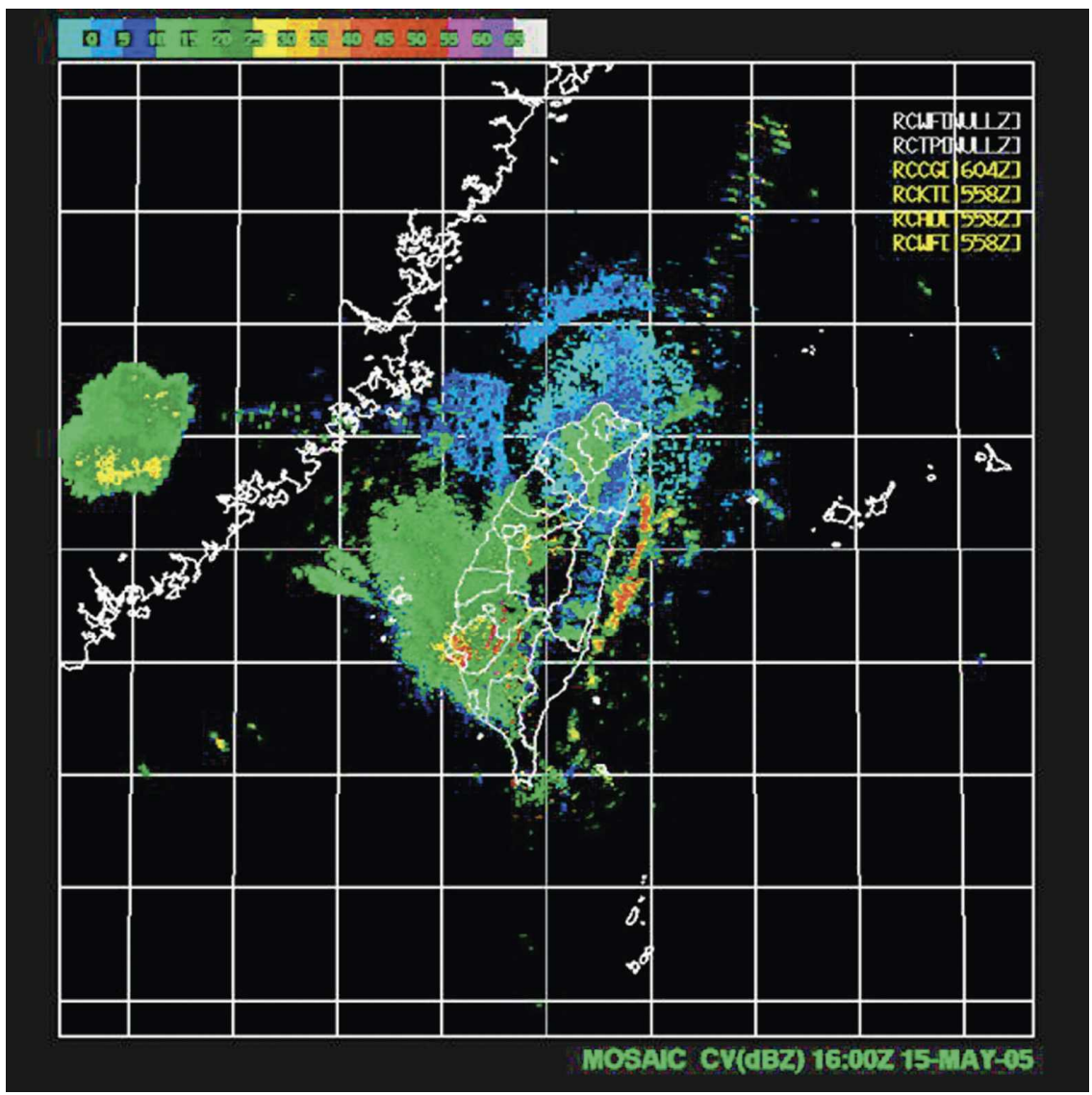

FIG. 15. Weather radar image acquired at 1600 UTC 15 May 2005 (0000 LST 16 May), that is, $10 \mathrm{~h}, 24 \mathrm{~min}$ before the ERS-2 SAR data acquisition.

\section{b. Land breeze/katabatic wind}

Another possible source of the offshore wind is a land breeze/katabatic wind. Land breeze as well as katabatic wind are both thermally driven winds that are generated by the differential diurnal heating of air over land and ocean surfaces. In mountainous areas, a land breeze is always commingled with katabatic wind, which is a drainage flow of cold air flowing downhill. They each require radiation cooling of air over land surfaces. Typically 1-2 $\mathrm{h}$ after sunset, cold air starts flowing down the mountain slopes and stops $1-2 \mathrm{~h}$ after sunrise. The land breeze/katabatic wind is strong when there are no clouds, when the winds are light, and when the humidity is low.

A schematic plot showing the airflow system where the offshore airflow is caused by land breeze/katabatic wind is depicted in Fig. 17. Cold air flows downhill and then spreads over the sea as a density current. As it moves seaward, the shallow layer of cold air is modified by convection and the layer thickness and its temperature increase toward the frontal line. At the conver- gence zone where both airflows collide, air is forced to move upward, which often gives rise to the formation of coast-parallel cloud bands. Note that Fig. 17 is a schematic plot, which does not show the circulation pattern

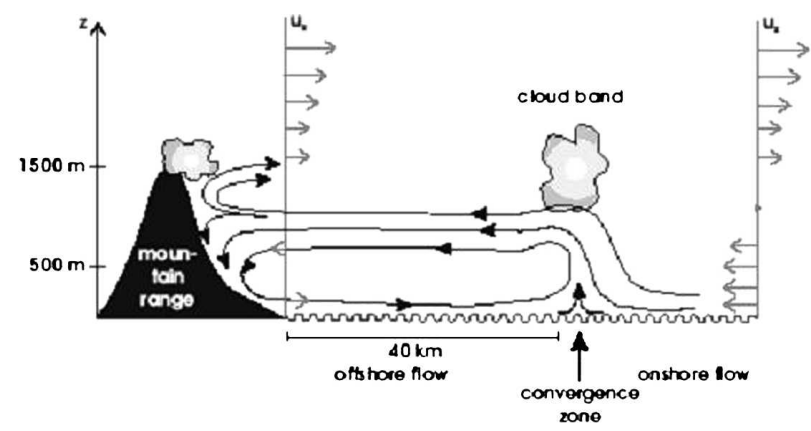

FIG. 16. Schematic plot of the airflow for the case when the recirculation of air causes the formation of the coast-parallel atmospheric front. The left and right vertical lines with the horizontal arrows attached denote the horizontal components of the wind vectors close to the shoreline and east of the convergence line, respectively. 


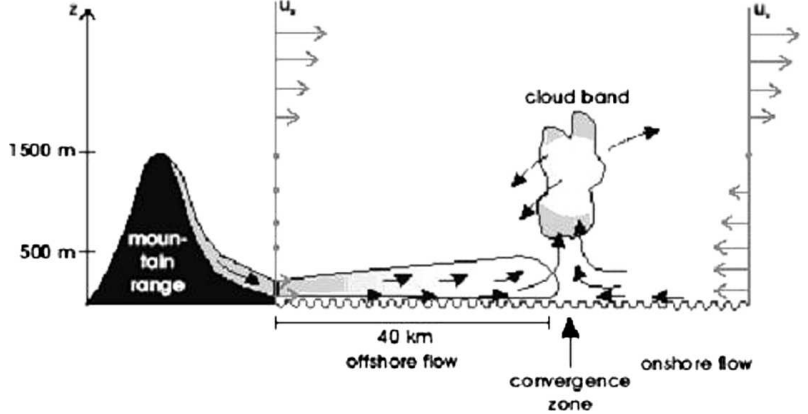

FIG. 17. Same as in Fig. 16, but for land breeze/katabatic wind. Note that this is a schematic plot, which does not show the circulation pattern at a fixed time. At 1025 LST (the time of the SAR observations), the flow of cold air from the mountain slope has already ended.

at a fixed time. At 1025 LST, the time of the ERS SAR data acquisitions, the flow of cold air from the mountain slope should have already terminated and a seabreeze circulation cell should have started building up close to the coastline.

At first sight, one would tend to discard the hypothesis that land breeze/katabatic wind causes the generation of the atmospheric front. The main reasons are the following. 1) The fronts are observed on SAR images acquired late in the morning (1025 LST). At this time, the land breeze/katabatic wind should have stopped and sea breeze should have taken over. Land breeze/ katabatic wind usually starts blowing toward the coast 1-2 $\mathrm{h}$ after sunrise. 2) The fronts have also been observed when the mountains were covered by clouds, that is, when no significant radiation cooling should have taken place. 3) The offshore distance of the frontal lines visible on the ERS SAR images presented in section 2 is $30-70 \mathrm{~km}$, which is too large for land breeze/ katabatic winds.

However, argument 1 is wrong and arguments 2 and 3 can be challenged. Concerning argument 1 (the time argument), one has to realize that the land breeze/ katabatic wind front can persist over the ocean many hours after the sea breeze has set in at the coast. The land breeze front propagates offshore as a density current and continues moving offshore even as the wind close to the coast switches to onshore. Sea-breeze circulation starts out immediately adjacent to the coast and then expands. It can take several hours before the sea-breeze front reaches the land breeze/katabatic wind front such that it can push it back toward the coast. However, we expect that in most cases the land breeze/ katabatic wind front has already dissipated before it is reached by the sea-breeze front. We may estimate the time that the sea breeze front needs to reach the land breeze/katabatic wind front by taking $2 \mathrm{~m} \mathrm{~s}^{-1}$ as a typi- cal value for the propagation speed of a sea-breeze front (Wexler 1946). With this value we find that it takes about $4 \mathrm{~h}$ for the sea-breeze front to travel $29 \mathrm{~km}$. But measurements also exist that show that land breeze fronts can be present over the ocean late in the morning and early in the afternoon. For example, in an experiment carried out on 29 August 1969 with an ultrasensitive ground-based radar located at Wallops Island, Virginia, Meyer (1971) showed that the land breeze front moved seaward between 0817 and 0916 LST. As the local circulation during daylight hours changed to sea breeze, the land breeze front receded toward land between 0916 and 1306 LST and then dissipated. The maximum seaward penetration from the beach occurred at 0916 LST, when the front had an offshore distance of $26 \mathrm{~km}$. This time is only $1 \mathrm{~h}$ earlier than the time at which we have observed atmospheric fronts on ERS SAR images off the east coast of Taiwan.

Concerning argument 2 (the cloud cover argument), one would expect that strong atmospheric fronts are generated only on those days with strong radiation cooling, that is, on cloud-free days where a large difference in air temperature over land and water exists. But this is not observed. One could argue that the clouds visible on the satellite images over Taiwan may have been predominantly high-level clouds, which do not inhibit radiation cooling very much. However, an argument against this hypothesis is that often the clouds seem to be mostly orographic clouds that are formed locally and stay on top of the coastal mountain range and sometimes also on top of the Central Mountain Range, as evidenced by high-resolution MODIS cloud images (see Fig. 6).

Concerning argument 3 (the frontal distance), one would expect that, in general, the atmospheric fronts are located too far from the coast to be explainable by land breeze/katabatic wind. But one may argue that the exceptional environment encountered in this region gives rise to very strong thermally driven offshore winds. Due to the strong radiation cooling of large volumes of air in the mountain area, the downhill flow of cool air could be very strong such that it advances very far over the sea. It is well known that the range of sea and land breeze in tropical and subtropical regions is quite large. For example, the seaward extension of the sea breeze from the north coast of Sumatra has been detected on a small island, Poeloe Bodjo, at a distance of $125 \mathrm{~km}$ (Wexler 1946). Furthermore, one can find in Simpson (1994) a photograph that was taken from Gemini 11 on 14 September 1966 that shows that around the southern tip of India, the sea-breeze area extends as far as $120 \mathrm{~km}$ out to sea.

Recently, Yu and Jou (2005) have studied offshore 
convective lines along the southeastern coast of Taiwan in the period 11-15 May 1998 during the mei-yu season by using a ground-based Doppler radar stationed at Green Island, which is an island located approximately $40 \mathrm{~km}$ east of the Taiwanese town of Taitung on the southeastern coast of Taiwan. They observed convective lines or rainbands that were oriented roughly parallel to the southeastern coast of Taiwan at a distance of $10-30 \mathrm{~km}$ offshore. The lines were marked by multiple centers of heavy precipitation concentrated within an elongated and narrow 5-10-km-wide zone. The intensity of precipitation associated with the offshore convective line clearly exhibited a pronounced diurnal variation. The lines tended to develop at night and rapidly weakened and dissipated after sunrise. The synoptic environment during their observational period was quite similar to the ones encountered during the events described in this paper. Prevailing wind brought a weak onshore flow of $2-3 \mathrm{~m} \mathrm{~s}^{-1}$ on the eastern coast of Taiwan. During the observational period, radiation cooling over land took place and thus a land breeze/katabatic wind developed after sunset. Yu and Jou (2005) attribute the offshore flow to land breeze/katabatic winds.

However, the convective lines detected by their ground-based radar are not necessarily identical to the atmospheric fronts detected on the ERS SAR images shown in this paper. First, Yu and Jou (2005) observed rainbands, while we observe frontal lines characterized by different wind stress at the sea surface at both sides of the front. Second, they observed alongshore rainbands in the evening and at night, while we observe alongshore atmospheric fronts late in the morning. Third, the alongshore rainbands, which they observed in the southern section of the east coast of Taiwan, are located 10-30 km offshore, while our frontal lines in the central section are located 30-70 km offshore.

$\mathrm{Yu}$ and Jou (2005) present in their paper strong evidence that the convective lines that they observed in the southern section of the east coast of Taiwan were generated by a land breeze/katabatic wind. They show that the time evolution of the rainbands is strongly correlated with the land-sea breeze cycle. Thus, one might expect that the same mechanism is causing the frontal lines that we have detected on several ERS SAR images and that extend east of the whole east coast of Taiwan.

\section{Conclusions}

We conclude that the frontal features visible on the ERS SAR images presented in this paper are not sea surface manifestations of the Kuroshio front but are sea surface manifestations of a coastal atmospheric front caused by the collision of two airflows from opposite directions. The first airflow originates from a (weak) onshore synoptic-scale wind and the second one from an offshore wind. We hypothesize that the offshore wind results partially from flow reversal of the onshore blowing synoptic-scale wind and partially from thermally driven land breeze/katabatic wind. Although the atmospheric fronts can persist over a longer period, their position from the coastline exhibits pronounced diurnal variations, which can be explained only by the presence of a downslope density current or thermally driven land breeze/katabatic wind. We conclude that this thermally driven wind plays an important role in the formation and time evolution of the atmospheric front off the east coast of Taiwan.

To have an in-depth understanding of the physical mechanism leading to the formation of the coastparallel atmospheric fronts off the east coast of Taiwan, one has to carry out simulations with a high-resolution atmospheric model and compare the results with observations. This task was beyond the scope of the present paper and is deferred to a subsequent paper.

Acknowledgments. We thank Prof. Wu-Ron Hsu of the Department of Atmospheric Sciences of the National Taiwan University (NTU) for very fruitful discussions on the theoretical interpretation of the data and Dr. Jing-Shan Hong of the Central Weather Bureau in Taipei for providing the weather radar data. We thank Iris Alpers for drawing the schematic plots of the airflows. This research was supported by the Grants NSC 94-2119-M-002-019-AP1 and NSC 94-2611-M-002011 and the partnership project between the University of Hamburg and NTU.

\section{REFERENCES}

Alpers, W., U. Pahl, and G. Gross, 1998: Katabatic wind fields in coastal areas studied by ERS-1 synthetic aperture radar imagery and numerical modeling. J. Geophys. Res., 103, 78757886.

Bosart, L. F., 1975: New England coastal frontogenesis. Quart. J. Roy. Meteor. Soc., 101, 735-744.

— C. J. Vaudo, and J. H. Helsdon Jr., 1972: Coastal frontogenesis. J. Appl. Meteor., 11, 1236-1258.

Chen, G. T.-J., 1983: Observational aspects of the Mey-Yu phenomenon in subtropical China. J. Meteor. Soc. Japan, 61, 306312.

Hsu, M.-K., L. M. Mitnik, V. B. Labonov, Ch.-T. Liu, and N. V. Bulatov, 1997: Kuroshio front and oceanic phenomena near Taiwan and in the southern Okhotsk sea from ERS SAR data. Proc. Third ERS Symp., ESA publication SP-414, Vol. 3, Florence, Italy, ESA, 1259-1266.

Huang, C.-Y., 1993: Numerical modelling of topographic influences on shallow front formation and evolution: Quasi- 
stationary coastal front. Terr. Atmos. Oceanic Sci., 4, 201216.

Ivanov, A. Y., W. Alpers, K. Ts. Litovchenko, M.-X. He, Q. Feng, M. Fang, and X.-H. Yan, 2004: Atmospheric front over the East China Sea studied by multi-sensor satellite and in-situ data. J. Geophys. Res., 109, C12001, doi:10.1029/2004JC002432.

Melsheimer, Ch., W. Alpers, and M. Gade, 2001: Simultaneous observations of rain cells over the ocean by the synthetic aperture radar aboard the ERS satellites and by surfacebased weather radars. J. Geophys. Res., 106, 4656-4677.

Meyer, J. H., 1971: Radar observations of land breeze fronts. $J$. Appl. Meteor., 10, 1224-1232.

Oekland, H., 1990: The dynamics of troughs and coastal fronts. Tellus, 42A, 444-462.

Rasmussen, R. M., and P. K. Smolarkiewicz, 1993: On the dynamics of Hawaiian cloud bands. Part III: Local aspects. J. Atmos. Sci., 50, 1560-1572.

— - _ cloud bands: Comparison of model results with observations and island climatology. J. Atmos. Sci., 46, 1589-1608.

Roeloffzen, J. C., W. D. van den Berg, and J. Oerlemans, 1986: Frictional convergence at coastlines. Tellus, 38A, 397-411.

Sikora, T. D., D. R. Thompson, G. S. Young, and N. S. Winstead,
1996: Evidence of a land breeze circulation in an ERS-1 SAR image of the New Jersey coastline. Proc. Int. Geoscience and Remote Sensing Symp., Lincoln, NB, IEEE, 893-895.

Simpson, J. E., 1994: Sea Breeze and Local Wind. Cambridge University Press, $234 \mathrm{pp}$.

Smolarkiewicz, P. K., R. M. Rasmussen, and T. L. Clark, 1988: On the dynamics of Hawaiian cloud bands: Island forcing. J. Atmos. Sci., 45, 1872-1905.

Valenzuela, G. R., 1978: Theories for the interaction of electromagnetic and oceanic waves: A review. Bound.-Layer Meteor., 13, 61-85.

Wexler, R., 1946: Theory and observations of land and sea breeze. Bull. Amer. Meteor. Soc., 27, 272-287.

Winstead, N. S., and P. D. Mourad, 2000: Shallow Great Lakescale atmospheric thermal circulation imaged by synthetic aperture radar. Mon. Wea. Rev., 128, 3654-3663.

Young, G. S., T. N. Sikora, and N. S. Winstead, 2005: Use of synthetic aperture radar in finescale surface analysis of synopticscale fronts at sea. Wea. Forecasting, 20, 311-327.

Yu, Ch.-K., and B. J.-D. Jou, 2005: Radar observations of the diurnally forced offshore convective lines along the southeastern coast of Taiwan. Mon. Wea. Rev., 133, 1613-1636. 